\title{
Educational Planning and Academic Achievement of Middle School Students: A Racial and Cultural Comparison
}

\author{
Wei-Cheng Mau
}

\begin{abstract}
A nationally representative sample of middle school students from diverse cultural and ethnic backgrounds was surveyed on educational aspirations, planning, and achievements. Results indicated significant racial and gender differences in educational and vocational planning help seeking behaviors. Results also indicated a significant race and sex interaction in students' educational aspirations as well as perception of parental expectations. Students' educational aspirations were significantly related to their current academic achievements. In many cases, students' aspirations and perceived parents' expectations did not match closely. Significant differences in mathematics, science, and reading proficiency among racial and sex groups also were indicated. Implications for counseling are discussed.
\end{abstract}

In a recent American Counseling Association (ACA) position paper, The School Counselor and Comprehensive Programs for Work-Bound Youth, Herr (1992) asserted that schooling, human development, and economic development are now linked in this nation in an irreversible fashion. Thus, connecting students' learning in school with the world of work is more important than ever. Students must demonstrate not only basic skills in reading, writing, arithmetic, and mathematical operations but also demonstrate higher-order thinking skills in making decisions and solving problems, as well as effectively applying personal qualities in self-management (SCANS Report, U.S. Department of Labor, 1991). If our schools fail to graduate students with these skills, graduates will not be able to compete in the global marketplace.

As the National Commission on Excellence in Education (1983) warned a decade ago, "The educational foundations of our society are being eroded by a rising tide of mediocrity that threatens our very future as a nation and a people" (p. 5). Data recently reported by Baker (1993) and Stevenson (1992) indicated that U.S. students are behind many other countries in academic performance. In responding to this educational crisis and its potential economic impact, ACA (Herr, 1992) has taken the position that it is the quality of human resources, not raw material or equipment, that needs to be developed. As cited in the ACA position paper, "The key factor in this or any other nation's ability to compete in the emerging international economic environment is the quality of the nation's work force as defined by its literacy, numeracy, flexibility, and teachability" (p. 1). As counselors, we believe that improving guidance and counseling services in the schools can contribute to enhancing the quality of the nation and its work force (Commission on Precollege Guidance and Counseling, 1986). American counselors can serve as experts in developing our human resources and in helping our students to link their education and the world of work.

Today's adolescents will join a workforce with new demographics. About $75 \%$ of the entering labor force in the United States (U.S.) is now composed of minorities, women, and immigrants (Sue, 1992). Minorities and women will account for more than $90 \%$ of all labor force growth by the year 2000 (Apolloni, Feichtner, \& West, 1991). In addition to changing demographics, higher levels of skill and educational training will be required (Bound \& Johnson, 1992). Persons with less than a high school education will face a difficult job search.

The nation's economic future depends on higher levels of educational attainment from those now at the bottom of the economic ladder. Unless students from this segment of society are prepared and encouraged to enter higher education, the percentage of college graduates among the adult labor force will decline (Commission on Precollege Guidance and Counseling, 1986). Many current middle school students will enter the work force by the year 2000. The competitiveness of the workplace dictates that 
today's students receive appropriate educational training and career guidance. Adolescents are in the crucial stage of "exploring" and "crystallizing" their career options (Super, 1969). They must decide whether to take a vocational track, a college preparatory track, or other options such as an apprenticeship training program (U.S. Department of Labor, 1992). George (1990) strongly urged that students begin receiving information on educational and career planning in the eighth grade. National survey results suggested that more than 6 out of 10 adults would get more information about careers and options if they could start over (Brown, Minor, \& Jepsen, 1991). Therefore, it is very important to examine eighthgrade students' educational planning, achievement, and aspirations. This knowledge will enable counselors to help students make a smoother transition from school to work or school to further education.

Census figures show that students in public schools after the year 2000 will have racially and culturally diverse backgrounds (U.S. Bureau of the Census, 1990). The diversification of the U.S. population has major implications for professional counselors and school administrators. Counseling services will need to be structured to optimize utilization by different minority populations who traditionally have not been well served by the schools (Commission on Precollege Guidance and Counseling, 1986). Findings based on a nationally representative high school student sample indicated that students of minority background are less likely to access guidance counseling for making important educational and vocational decisions than are White students (Lee \& Estrom 1987). Although schools and universities often compete to recruit minority students, little is known about these students' needs, academic performance, and future plans (Kerr, Colangelo, Maxey, \& Christensen, 1992). Counselors will be more effective if they are sensitive to the educational and vocational needs of different ethnic minority students. Therefore, information regarding the educational and vocational planning of these students is needed to provide them with effective counseling services.

Ethnic minority students face special obstacles not only in school but also in the working world (Brooks, 1984). Minorities are concentrated in a restricted range of occupations, are likely to be unemployed, earn Jess, and, consequently, are more likely to live in poverty (Arbono, 1990). According to the U.S. Department of Labor's Opportunity 2000 report (1988), minority workers continue to suffer disadvantages in education and training that prevent them from moving into the new jobs that are becoming available. Blacks and Hispanics are overrepresented in industries that are losing jobs and are underrepresented in the most rapidly growing occupations. Even Asian Americans, the "model" minority, are limited by the stereotype of excellence in science and math, resulting in underrepresentation in top management positions (Fukuyama \& Cox, 1992). Although according to the maxim "What you learn determines what you earn," for many minorities and women, education may not necessarily translate into equivalent earning power. Discrimination and stereotyping should be taken into consideration when analyzing and helping with minority persons' career development (Smith, 1975). An understanding of these obstacles as they relate to minority students' career aspirations and educational endeavors can improve counselors' effectiveness in helping students to achieve their career goals.

Over the last two decades, minority counseling issues have emerged in the literature (Hoyt, 1989; Ponterotto, 1988; Thompson \& Atkinson, 1991). Issues relating to Black and Hispanic Americans have been explored more than have those relating to Asian and Native Americans (Smith, 1983). The limited research on career behaviors of racial minorities has involved late adolescent and young adult populations. In my review of the literature, I did not find a study of early adolescents that compared the educational and vocational aspirations and planning of minority groups.

In this study, I examined data from a nationally representative sample of eighth-grade students. Of particular interest were the educational planning behaviors, educational aspirations, and math, science, and reading proficiencies of different racial and ethnic groups. The primary research questions were the following: 
1. How active are these students in planning their high school programs?

2. How do these racial-ethnic and sex groups compare in their levels of academic achievement as well as educational aspirations?

Perceived parental educational expectations (e.g., Kerckhoff, 1989; Otto \& Haller, 1979; Smith, 1991) and students' academic achievement (e.g., Blau \& Duncan, 1967; Sewell \& Hauser, 1980) have been considered by many as important variables that influence the White majority's status attainment process. Little, however, is known about how these variables influence minority students' educational and vocational attainment. Therefore, the secondary questions of this study were the following:

3. How do students' aspirations compare with their perceptions of their parents' expectations?

4. Are students' educational aspirations associated with their current academic achievements?

\section{METHOD}

Participants

The data of this study were obtained from the National Educational Longitudinal Study of 1988 NELS:88), sponsored by the National Center for Educational Statistics (NCES, 1990a). NELS:88 is the third and most recent in a series of longitudinal studies designed to provide timely information on trends in academic achievement. Participants were 24,599 eighth-grade students (12,111 boys, 12,244 girls, and 244 no response) in 1,052 U.S. schools. The racial-ethnic composition of this sample was 1,527 Asian American (6.2\%), 3,171 Hispanic (12.9\%), 3,009 Black (12.2\%), 15,692 White (63.8\%), and 924 Native American (3.8\%) students.

The NELS:88 sampling procedure was carefully designed and implemented to ensure a nationally representative sample of schools and students. To accomplish the needed representative sample, a two stage probability design was used. For the first stage, a stratified sampling of 1,734 public and private schools was selected, of which 1,052 schools participated. The second stage included random samples of $25( \pm 1)$ students per sampled school, resulting in participation by 24,599 eighth-grade students. The school sample was stratified by size, urban versus rural, regional, and percent minority population. Samples were weighted to compensate for unequal probabilities of selection and to adjust for nonresponse rates. Asian American and Hispanic students were oversampled to ensure adequate sample sizes for subgroup analyses. The detailed sampling procedure is described by the National Center for Educational Statistics (1990b).

\section{Instruments}

Students completed a 45-minute self-administered questionnaire in their classrooms. The questionnaire was designed to collect information about a wide range of topics, including students' and parents' backgrounds, perception of self, students' educational and vocational activities, postgraduation plans, and aspirations. Students also completed an 85-minute battery of cognitive tests (reading, mathematics, science, and social studies). The variables reported here include educational planning, educational aspirations, and math, science, and reading proficiency.

Educational planning. The variable of educational planning was measured by the number of consultations that students had with their counselors, teachers, adult relatives, or friends about planning their high school program. Two questions were asked. The first question was phrased "How often have you talked to the following people about planning your high school program?" Students indicated the frequency of consultations with helpers including father, mother, counselor, teacher, adult relatives, and peer friends. The response categories were not at all, once or twice, and three or more times. The last two 
response categories were combined for data analysis, making interpretation easier. These dichotomized response categories were not at all and at least once.

The second question was phrased "Since the beginning of this school year, have you talked to a counselor at your school, a teacher at your school, or another adult relative or adult friend (other than your parent), for any of the following reasons?" Students responded with a yes or no to the following reasons: "(a) To get information about high schools or high school programs; (b) To get information about jobs or careers that you might be interested in after finishing school; (c) To help improve your academic work in school right now; and (d) To select courses or programs at school." The variable score for the second question was derived from summing the frequencies of yes responses to each of the reasons on each target person.

Educational aspirations. The variable of educational aspirations was measured by the survey question "As things stand now, how far in school do you think you will go?" The responses were coded from 1 to 6: 1 = Won't finish high school, 2 = Will graduate from high school, 3 = Will go to vocational school, $4=$ Will attend college, $5=$ Will graduate from college, and $6=$ Will attend a higher level of school after graduating from college. The same response categories and coding were used for students' perceptions of their parents' expectations. This question was phrased as "How far in school do you think your father and your mother want you to get?" Students re-corded their perceptions for each parent separately, and the average score was used.

Math, science, and reading proficiency. These three variables were measured by three cognitive tests (developed by Educational Testing Service [ETS]): mathematics (40 items), science (25 items), and reading (21 items). According to the Psychometric Report for the NELS: 88: Base Year Test Battery (NCES, 1991), the primary purpose of this test battery was to obtain an accurate measurement of the status of individuals at a given point in time as well as their growth over time. The reading test consisted of five short passages followed by comprehension and interpretation questions. The values for overall reading proficiency were reported as $1=$ below level 1, $2=$ at level $\mathrm{J}$, and $3=$ at level 2 . Science questions were constructed to assess science knowledge and science reasoning. The science test was scored with quartiles: 1 = quartile 1, 2 = quartile 2, 3 =quartile 3, and 4 = quartile 4 . The mathematics test consisted of quantitative comparisons and other questions containing word problems, diagrams, and calculations. Overall mathematics proficiency was reported as $1=$ below level 1, $2=$ at level 1, $3=$ mastered both levels 1 and 2, and $4=$ mastered the two lower proficiency levels and can solve simple problem-solving tasks successfully. Internal consistency measures based on coefficient alpha for math, science, and reading tests were $.90, .75$, and .84. Based on the Mantel-Haenszel odds-ratio analyses (Holland \& Thayer, 1986), there was little evidence of differential item functioning for either sex or racial-ethnic group. Factor analytic results supported the discriminant validity of the three content areas. Convergent validity also was indicated on the hypothesized factors. Detailed information can be found in the NCES's (1991)

Psychometric Report for the NELS:88: Base Year Test Battery.

\section{Data Analysis}

The first survey question ("How often have you talked to the following people about planning your high school program?") was analyzed using a chi-square test of independence on whether or not students consulted a helper (at least once or not at all) and students' ethnic origin ( $2 \times 5)$ and sex ( $2 \times 2)$. The percentages of each racial group's response to each helper category also were calculated (see Table 1). The secondary survey question ("Since the beginning of this school year, have you talked to a counselor at your school, a teacher at your school, or another adult relative or friend [other than your parents] for any of the following reasons?") was also analyzed using chi- square for each reason. Family-wise error rates were used in determining the alpha level for significance. This was accomplished by dividing .05 by the number of chi-square tests for each research question. For the first survey question, an alpha of .008 
(.05 divided by 6) was required for significance. For the second survey question, an alpha of .004 (.05 divided by 12) was required for significance.

Because the chi-square statistic itself is too sensitive to large samples, $f$ (phi coefficient) statistics were used. The phi coefficient is a modification of the chi-square statistic to minimize the influence of sample size and degrees of freedom. The phi coefficients were computed using the following formula: $\phi=$ $\left(x^{2} / N\right)^{1 / 2}$ (SPSS, 1990).

Students' educational aspirations and academic achievement were analyzed using two-way 5 (Race) $\times 2$ (Sex) analyses of variance (ANOVAs). When no significant interaction was found, main effects were investigated with the Scheffe procedure. Significant interactions between race and sex were examined using one-way ANOVAs and Scheffe follow-up tests within each group.

\section{RESULTS}

\section{Educational Planning}

Results from the first survey question are summarized in Table 1. Significant differences were found among racial groups in seeking help from different people for high school planning. Black students were more likely than were others to consult their mothers (90.5\%; $\phi=.05, p<.0001)$, counselors $(39.9 \%, \phi=$ $.04, p<.0001)$, teachers (56.2\%; $\phi=.07, p<.0001)$, relatives $(77.2 \% ; \phi=.11, p<.0001)$, and friends (88.8\%; $\phi=.03, p<.0001)$. Asian American students were more likely than were others to consult their fathers about planning their high school programs $(80.9 \% ; \phi=.11, p=.0001)$.

Significant gender differences in high school planning also were found for all helpers consulted except for "counselor." Girls were more likely than were boys to consult their mothers $(\phi=.07, p<$ $.0001)$, teachers $(\phi=.02, p<.001)$, relatives $(\phi=.10, p<.0001)$ and friends $(\phi=.15, p<.0001)$. Boys were more likely than were girls to consult their fathers $(\phi=.03, p<.0001)$. Boys $(87 \%)$ were most likely to consult their mothers, whereas girls (91.7\%) were most likely to consult their friends for high school planning. Counselor were the least consulted helpers, but were sought equally by boys (35.2\%) and girls (35.1\%). Overall, regardless of race or sex, student reported that they consulted nonschool persons (e.g., mothers and friends) more frequently than they consulted school persons (e.g. teachers and counselors) about high school programs.

Table 1

Percentage of Student Groups Seeking Help with Planning Their High School Program

\begin{tabular}{|c|c|c|c|c|c|c|c|c|c|}
\hline Helper & $\begin{array}{c}\text { Asian } \\
\text { American } \\
(\mathrm{n}=\mathbf{1 , 5 2 7})\end{array}$ & $\begin{array}{c}\text { Hispanic } \\
(n=3,171)\end{array}$ & $\begin{array}{c}\text { Black } \\
\text { (n }=3,009)\end{array}$ & $\begin{array}{c}\text { White } \\
(n=15,692)\end{array}$ & $\begin{array}{l}\text { Native } \\
\text { American } \\
(n=924)\end{array}$ & $\phi^{a}$ & $\begin{array}{c}\text { Boys } \\
(n=12,111)\end{array}$ & $\begin{array}{c}\text { Girls } \\
(\mathrm{n}=12,244)\end{array}$ & $\phi^{a}$ \\
\hline Father & $8 Q .9^{b}$ & 70.8 & 63.3 & 77.1 & 68.9 & $.11^{* *}$ & 75.9 & 73.1 & $.03 * *$ \\
\hline Mother & 85.3 & 87.2 & 90.5 & 89.9 & 84.9 & $.05^{* *}$ & 87.0 & 91.1 & $.07 * *$ \\
\hline Counselor & 36.0 & 31.9 & 39.9 & 35.1 & 32.2 & $.04 * *$ & 35.2 & 35.1 & .00 \\
\hline Teacher & 48.3 & 45.6 & 56.2 & 46.0 & 42.0 & $.07 * *$ & 45.9 & 48.3 & $.02 *$ \\
\hline Relatives & 62.7 & 70.9 & 77.2 & 61.7 & 67.0 & $.11^{* *}$ & 59.9 & 69.8 & $.10 * *$ \\
\hline Friends & 88.4 & 86.0 & 88.8 & 86.4 & 84.8 & $.03^{*}$ & 81.5 & 91.7 & $.15^{* *}$ \\
\hline
\end{tabular}

${ }^{a}$ Based on percentage of students who have sought help from the designated helper at least once.

${ }^{b}$ Based on the $\phi$ (phi-coefficient) statistics. $\phi=\left(x^{2} / N\right)^{1 / 2}$

${ }^{*} p<.001 .{ }^{*} p<.0001$.

Significant gender differences in high school planning also were found for all helpers consulted except for "counselor." Girls were more likely than were boys to consult their mothers $(\phi=.07, p<.0001)$, teachers $(\phi=.02, p<.001)$, relatives $(\phi=.10, p<.0001)$, and friends $(\phi=.15, p<.0001)$. Boys were more likely than were girls to consult their fathers $(\phi=.03, p<.0001)$. Boys $(87 \%)$ were most likely to consult their mothers, whereas girls (91.7\%) were most likely to consult their friends for high school planning. 
Counselors were the least consulted helpers, but were sought equally by boys (35.2\%) and girls (35.1\% ). Overall, regardless of race or sex, students reported that they consulted nonschool persons (e.g., mothers and friends) more frequently than they consulted school persons (e.g., teachers and counselors) about high school programs.

Results from chi-square analyses based on the second survey question showed significant differences among racial-ethnic groups in obtaining help for educational or vocational concerns. Table 2 presents percentages for each racial-ethnic and sex group that sought help from each source (i.e., counselor, teacher, friend, or relative) for each help-seeking reason. Black students reported that they were more likely than were others to talk to a counselor $(48.9 \% ; \phi=.10, p<.0001)$, a teacher $(52.9 \% ; \phi$ $=.10, \mathrm{p}<.0001)$, or their friends or relatives $(62.5 \% ; \phi=.08, \mathrm{p}<.0001)$ to get information about high schools or high school programs. Black students were more likely than were other students to talk to a counselor (33. 7\%; $\phi=.15, p<.0001)$, a teacher (34.9\%; $\phi=.12, p<.0001)$, or friends or relatives $(72.2 \%$; $\phi=.10, \mathrm{p}<.0001)$ to get information about jobs or careers. Black students were more likely than were other students to talk to a counselor $(35.0 \% ; \phi=.13, \mathrm{p}<.0001)$ or a teacher $(71.3 \% ; \phi=.08, \mathrm{p}<.0001)$, and Native American students were more likely than were others to talk to friends or relatives (56.9\%; $\phi$ $=.08, \mathrm{p}<.0001$ ) to help improve their academic work in school. Black students were more likely than were other students to talk to a counselor $(46.4 \% ; \phi=.06, p<.0001)$ or a teacher $(52.6 \% ; \phi=.06, p<.0001)$, and Native American students were more likely than were others to talk to their friends or relatives (61.4\%; $\phi=.03, p<.0001$ ) to select school courses or programs.

Gender differences in selecting helpers also were significant, but to a lesser degree than were racial-ethnic differences. Female students reported that they were more likely than were male students to seek friends or relatives $(\phi=.04, p<.0001)$ to get information about high schools or high school programs. Male students were more likely than were female students to ask a counselor $(\phi=.03, p<$ $.0001)$ or a teacher $(\phi=.02, p<.001)$ to get information about jobs or careers. Male students were more likely than were female students to ask a counselor $(\phi=.05, p<.0001)$ for help in improving academic work. Female students were more likely than were male students to consult a teacher $(f=.02, p<.001)$ or friends or relatives $(\phi=.05, p<.0001)$ when selecting courses or programs at school.

Regardless of sex or racial-ethnic background, students reported that they were more likely to seek help from their friends or relatives than from their teachers or counselor. The only exception was that a teacher was most often sought to help improve academic work. Overall, students were most likely to ask help in selecting school courses and least likely to seek help for job or career information. White students, in general, were less likely to seek help than were minority students.

\section{Educational Aspiration}

Analysis of educational aspiration, using a two-way ANOVA, resulted in significant effects for race, $F(4,24,322)=123.4, p<.0001 ;$ sex, $F(I, 24,355)=113.1, p<.0001 ;$ and race by sex interaction, $F(4,23,886)$ $=3.8, p<.01$. Because of the significant interaction, analyses were thereafter conducted within each racial and sex group. Table 3 provides a summary of means, standard deviations, and F tests for racial-ethnic and sex groups.

Scheffe follow-up tests indicated that Asian American boys had significantly higher educational aspirations than did any other male group, and Native American boys had significantly lower aspirations than did any other male group. Black male students and White male students had significantly higher aspirations than did Hispanic and Native American male students. Similarly, the educational aspirations of Asian American girls were significantly higher than were those of other female groups, and those of Hispanic and Native American girls were significantly lower than were those of other female groups. For each racial-ethnic group, female students had significantly higher educational aspirations than did male students.

To address the secondary questions of this study, I analyzed students' perceptions of parental 
expectations for their education (see Table 3). Two-way ANOVAs resulted in significant effects for race, $F(4,24,322)=70.1, p<.0001$; sex, $F(I, 24,355)=66.2, p<.0001$; and race by sex interaction, $F(4,23,886)$ $=3.6, p<.01$. Scheffe follow-up tests indicated that Asian American boys perceived significantly higher expectations than did any other male group, whereas Native American boys perceived lower expectations than did any other male group. Similarly, Asian American girls also perceived significantly higher parental expectations than did any other female group, whereas Native American girls perceived lower expectations than did any other female group. Within each racial-ethnic group, female students perceived significantly higher expectations than did male students. Overall mean scores for perceived parental expectations for each group were Asian American (S.3), Hispanic (4.8), Black (5.0), White (4.9), and Native American (4.6).

Additionally, differences between students' perceptions of parents' expectations and students' educational aspirations were compared. Two-way (Race by Sex) ANOVAs indicated significant main effects for race, $F(4,19,623)=22.0, p<.0001$; and sex, $F(4,19,623)=14.4, p<.0001$. There was no significant race-sex interaction, $F(4,19,623)=1.1, p<.34$. A one-way ANOVA indicated significant differences between students' aspirations and perceived-parent expectations among racial-ethnic groups, $\mathrm{F}(4$, $19,805)=22.9, p<.001$. Scheffe follow-up tests indicated that Native American and Hispanic students showed greater discrepancies than did Asian American and White students. Black students also showed greater discrepancies than did White students. Mean difference scores were Asian American (.17), Hispanic (.32), Black (.24), White (.15), and Native American (.37). For each racial-ethnic group, students' perceptions of their parents' aspirations for them exceeded their own. An ANOVA also indicated that male students showed significantly greater discrepancies than did female students, $F(4,19,817)=15.3, p<$ .0001 . Mean difference scores were .20 for male students and .15 for female students.

TABLE 2

Percentage of Student Groups Seeking Help for Different Reasons From Counselor, Teacher, or Friends/Relatives

\begin{tabular}{|c|c|c|c|c|c|c|c|c|c|}
\hline Reasons and Helpers & $\begin{array}{c}\text { Asian } \\
\text { American } \\
(n=1,527)\end{array}$ & $\begin{array}{l}\text { Hispanic } \\
(n=3,171)\end{array}$ & $\begin{array}{c}\text { Black } \\
(n=3,009)\end{array}$ & $\begin{array}{c}\text { White } \\
(n=15,692)\end{array}$ & $\begin{array}{c}\text { Native } \\
\text { American } \\
(n=924)\end{array}$ & $\phi^{\circ}$ & $\begin{array}{c}\text { Boys } \\
(n=12,111)\end{array}$ & $\begin{array}{c}\text { Girls } \\
(n=12,244)\end{array}$ & $\phi^{\prime \prime}$ \\
\hline \multicolumn{10}{|c|}{$\begin{array}{l}\text { A. To get information about high schools or high } \\
\text { school programs }\end{array}$} \\
\hline Counselor & $41.7^{\circ}$ & 39.6 & 48.9 & 34.4 & 34.6 & $.10^{* *}$ & 38.0 & 36.4 & .02 \\
\hline Teacher & 46.2 & 47.0 & 52.9 & 39.9 & 37.0 & $.10^{* *}$ & 42.3 & 43.0 & .01 \\
\hline Friends or relatives & 54.0 & 58.6 & 62.5 & 51.7 & 57.3 & $.08^{* *}$ & 52.1 & 56.2 & $.04 *$ \\
\hline \multicolumn{10}{|c|}{ B. To get information about jobs or careers } \\
\hline Counselor & 17.8 & 22.0 & 33.7 & 16.2 & 23.7 & $.15^{*}$ & 20.7 & 18.2 & $.03 *$ \\
\hline Teacher & 23.9 & 28.2 & 34.9 & 20.6 & 23.8 & $.12^{* *}$ & 24.6 & 22.9 & $.02^{*}$ \\
\hline Friends or relatives & 58.2 & 66.7 & 72.2 & 59.3 & 68.9 & $.10^{* *}$ & 62.7 & 61.5 & .01 \\
\hline \multicolumn{10}{|c|}{$\begin{array}{l}\text { C. To help improve your academic work in } \\
\text { school right now }\end{array}$} \\
\hline Counselor & 22.3 & 27.7 & 35.0 & 19.4 & 28.9 & $.13^{* *}$ & 25.1 & 20.7 & $.05^{* *}$ \\
\hline Teacher & 64.0 & 64.5 & 71.3 & 59.6 & 62.6 & $.08^{* *}$ & 62.0 & 62.1 & .00 \\
\hline Friends or relatives & 48.3 & 52.2 & 55.6 & 46.0 & 56.9 & $.08^{* *}$ & 48.0 & 49.2 & .01 \\
\hline \multicolumn{10}{|c|}{ D. To select courses or programs at school } \\
\hline Counselor & 42.0 & 41.2 & 46.4 & 37.9 & 39.2 & $.06^{* *}$ & 40.0 & 39.2 & .01 \\
\hline Teacher & 47.6 & 45.2 & 52.6 & 43.8 & 42.1 & $.06^{* *}$ & 44.1 & 46.2 & $.02^{*}$ \\
\hline
\end{tabular}

${ }^{a}$ Based on percentage of students who said that they consulted the designated helper. ${ }^{b}$ Based on the $\phi$ (phicoefficient) statistics. $\phi=\left(x^{2} / N\right)^{1 / 2}$

\section{Relationships Between Educational Achievement and Aspiration}

Table 4 provides means and standard deviations of academic achievement and their zero-order correlations with educational aspirations. Results revealed that educational aspirations were significantly associated with mathematics proficiency $(r=.35, p<.01)$, reading proficiency $(r=.29, p<.01)$, and science quartile $(r=.33, p<.01)$. The degree of association, however, was higher for the Asian American group ( $r$ 
$=.38, .27, .35)$ and the White American group $(r=.38, .32, .36)$ than it was for the Hispanic group $(r=.27$, $.24, .26)$, the Black American group $(r=.23, .21, .22)$, and the Native American group $(r=.21, .15, .23)$.

TABLE 3

Means, Standard Deviations, and F Values of Students' Educational Aspirations and Perceived Parents' Expectations, by Race and Sex

\begin{tabular}{|c|c|c|c|c|c|c|c|c|c|c|c|c|c|c|c|}
\hline \multirow[b]{2}{*}{ Item } & \multicolumn{2}{|c|}{$\begin{array}{c}\begin{array}{c}\text { Asian } \\
\text { American } \\
(n=1,527)\end{array} \\
\end{array}$} & \multicolumn{2}{|c|}{$\begin{array}{c}\text { Hispanic } \\
(n=3,171)\end{array}$} & \multicolumn{2}{|c|}{$\begin{array}{c}\text { Black } \\
(n=3,009)\end{array}$} & \multicolumn{2}{|c|}{$\begin{array}{c}\text { White } \\
(n=15,692) \\
\end{array}$} & \multicolumn{2}{|c|}{$\begin{array}{c}\begin{array}{c}\text { Native } \\
\text { American } \\
(n=924)\end{array} \\
\end{array}$} & \multirow{2}{*}{$\begin{array}{c}\text { Boys } \\
(n=12,111)\end{array}$} & \multirow{2}{*}{$\begin{array}{c}\text { Girls } \\
(n=12,244)\end{array}$} & \multirow{2}{*}{$\begin{array}{c}\text { Race (R) } \\
F(4,24,322)\end{array}$} & \multirow{2}{*}{$\begin{array}{c}\operatorname{Sex}(\mathbf{S}) \\
F(1,24,355)\end{array}$} & \multirow{2}{*}{$\begin{array}{c}\mathbf{R} \times \mathbf{S} \\
F(4,23,866)\end{array}$} \\
\hline & B & $\boldsymbol{G}$ & $B$ & G & $B$ & $\boldsymbol{G}$ & $B$ & G & $B$ & $\mathbf{G}$ & & & & & \\
\hline \multicolumn{16}{|c|}{ Aspired } \\
\hline$M$ & 5.0 & 5.2 & 4.2 & 4.4 & 4.5 & 4.7 & 4.6 & 4.7 & 3.9 & 4.4 & 4.5 & 4.7 & $123.4^{* *}$ & $113.1^{* *}$ & $3.8^{*}$ \\
\hline$S D$ & 1.2 & 1.0 & 1.5 & 1.4 & 1.3 & 1.3 & 1.3 & 1.2 & 1.4 & 1.3 & 1.3 & 1.2 & & & \\
\hline \multicolumn{16}{|c|}{ Perceived } \\
\hline$M$ & 5.3 & 5.4 & 4.7 & 4.9 & 4.9 & 5.0 & 4.8 & 5.0 & 4.5 & 4.8 & 4.8 & 5.0 & $70.1^{* *}$ & $66.2^{* *}$ & $3.6^{*}$ \\
\hline$S D$ & 0.8 & 0.8 & 1.2 & 1.2 & 1.1 & 1.1 & 1.0 & 1.0 & 1.2 & 1.2 & 1.1 & 1.1 & & & \\
\hline
\end{tabular}

Note. The response categories ranged from $1=$ won't finish high school to $6=$ will attend a higher level of school after graduating from college.

TABLE 4

Means Standard Deviations of Students' Academic Achievements and Their Zero-Order Correlations With Educational Aspirations

\begin{tabular}{|c|c|c|c|c|c|c|c|c|c|c|c|c|c|c|c|c|c|}
\hline \multirow[b]{2}{*}{ Proficiency Test } & \multicolumn{2}{|c|}{$\begin{array}{c}\text { Asian } \\
\text { American } \\
(n=1,527) \\
\end{array}$} & \multicolumn{2}{|c|}{$\begin{array}{c}\begin{array}{c}\text { Hispanic } \\
(n=3,171) \\
\end{array} \\
\end{array}$} & \multicolumn{2}{|c|}{$\begin{array}{c}\text { Black } \\
(n=3,009) \\
\end{array}$} & \multicolumn{2}{|c|}{$\begin{array}{c}\text { White } \\
(n=15,692) \\
\end{array}$} & \multicolumn{2}{|c|}{$\begin{array}{c}\text { Native } \\
\text { American } \\
(n=924) \\
\end{array}$} & \multicolumn{2}{|c|}{$\begin{array}{c}\text { Boys } \\
(n=12,111)\end{array}$} & \multicolumn{2}{|c|}{$\begin{array}{c}\text { Girls } \\
(n=12,244)\end{array}$} & \multirow[b]{2}{*}{ Race (R) } & \multirow[b]{2}{*}{$\operatorname{Sex}(\mathbf{S})$} & \multirow[b]{2}{*}{$\mathbf{R} \times \mathbf{S}$} \\
\hline & $M$ & SD & $M$ & $S D$ & $M$ & $S D$ & $M$ & $S D$ & $M$ & $S D$ & $M$ & SD & $M$ & $S D$ & & & \\
\hline Math & 2.90 & 1.00 & 2.10 & 0.90 & 2.00 & 0.90 & 2.60 & 1.00 & 2.10 & 0.90 & 2.50 & 1.00 & 2.46 & 1.00 & $350.5^{* *}$ & $436.0^{* *}$ & 1.7 \\
\hline Reading & 2.30 & 0.70 & 2.00 & 0.60 & 2.00 & 0.70 & 2.30 & 0.60 & 2.00 & 0.70 & 2.20 & 0.68 & 2.26 & 0.65 & $239.0^{* *}$ & $288.8^{* *}$ & 0.6 \\
\hline Science & 2.70 & 1.10 & 2.10 & 1.00 & 1.90 & 0.90 & 2.80 & 1.10 & 2.20 & 1.10 & 2.60 & 1.10 & 2.46 & 1.10 & $545.2^{* *}$ & $654.0^{* *}$ & 1.5 \\
\hline \multicolumn{18}{|c|}{ Zero-Order Correlation With Educational Aspiration } \\
\hline Math & \multicolumn{2}{|c|}{$.38^{*}$} & \multicolumn{2}{|c|}{$.27^{*}$} & \multicolumn{2}{|c|}{$.23^{*}$} & \multicolumn{2}{|c|}{$.38^{*}$} & \multicolumn{2}{|c|}{$.21^{*}$} & & & & & & & \\
\hline Reading & \multicolumn{2}{|c|}{$.27^{*}$} & \multicolumn{2}{|c|}{$.24^{*}$} & \multicolumn{2}{|c|}{$.21^{*}$} & \multicolumn{2}{|c|}{$.32^{*}$} & \multicolumn{2}{|c|}{$.15^{*}$} & & & & & & & \\
\hline Science & \multicolumn{2}{|c|}{$.35^{*}$} & \multicolumn{2}{|c|}{$.26^{*}$} & \multicolumn{2}{|c|}{$.22^{\circ}$} & \multicolumn{2}{|c|}{$.36^{*}$} & \multicolumn{2}{|c|}{$.23^{\circ}$} & & & & & & & \\
\hline
\end{tabular}

Note. Two overall ratings were reported that characterized the students' proficiency in reading and mathematics. The values for overall mathematics proficiency were the following: $1=$ below level $1,2=$ at level $1,3=$ mastered levels 1 and 2 , and $4=$ proficient at all three levels. The values for reading overall proficiency were the following: 1 $=$ below level 1, 2 = at level 1 , and $3=$ at level 2 . The science test was scored with quartiles: 1-quartile 1, 2-quartile 2, 3-quartile 3, and 4-quartile 4.

$* \mathrm{p}<.01 .{ }^{* *} \mathrm{p}<.0001$.

Two-way ANOVAs resulted in significant main effects for race in mathematics proficiency, $\mathrm{F}(4$, $21,508)=350.5, p<.0001$; science proficiency, $F(4,23,177)=545.0, p<.0001$; and reading proficiency, $F(4,22,276)=239.0, p<.0001$. Results also indicated main effects for gender in mathematics, $F(1,21,508)$ $=436.0, \mathrm{p}<.0001$; science, $F(1,23,177)=654.0, \mathrm{p}<.0001$; and reading, $F(1,22,276)=288.8, \mathrm{p}<.0001$. There was no significant interaction effect found in any of the proficiency tests.

Scheffe follow-up tests indicated that, on the average, the Asian American group ( $M=2.9$ ) scored significantly higher on the math proficiency test than did any other group, whereas the White student group ( $M=2.6$ ) scored significantly higher on this test than did Hispanic ( $M=2.1)$, Black $(M=2.0)$, and Native American student $(M=2.1)$ groups. For the reading and scenic proficiency tests, the Asian American group (reading, $M=2.3$; science, $M=2.7$ ) and the White student group (reading, $M=2.3$; science, $M=2.8$ ) scored significantly higher than did Hispanic (reading, $M=2.0$; science, $M=2.1$ ), Black (reading, $M=2.0$; science, $M=I .9$ ), and Native American (reading, $M=2.0$; science, $M=2.2$ ) groups. Also, for the science test, Hispanic ( $M=2.1$ ) and Native American $(M=2.2)$ groups scored significantly higher than did the Black student group. 
One-way follow-up tests on gender differences showed that male students scored significantly higher than did female students in mathematics, $F(1,22,543)=7.7, p<.006$, and science, $F(1,23,439)=$ $95.1, p<.0001$, tests. Female students, on the other hand, scored significantly higher than did male students on the reading test, $F(1,22,518)=39.9, p<.0001$.

In summary, the results of this study indicated that Black students were relatively more active in educational and vocational planning than was any other racial group. For all student groups, counselors and teachers were sought less often for help than were students' peers and relatives. There is some evidence that students' educational aspirations were related closely to their academic achievements. Hispanic and Native American students had the lowest educational aspirations and the lowest levels of academic achievement. Black students aspired to higher levels of education than did Hispanic and Native American students, but not as high as Asian American students. White students scored highest on science and reading tests and had the second highest level of educational aspiration. Asian Americans aspired to higher educational goals than did all other groups. They also scored higher than did other groups on math. In many cases, students' aspirations and perceived parental expectations did not match closely. For every group, female students had higher educational aspirations and higher perceived parental expectations than did male students.

\section{DISCUSSION}

In this study, I investigated minority students' educational planning, aspirations, and achievements. Based on the findings of this study, I suggest several implications for counseling practice, and I focus on how counselors can play a crucial role in young adolescents' educational and career development.

\section{Educational Planning}

Overall, results suggested that minority students, especially Black students, were relatively more active than were White students in planning their educational programs, and White students were less likely than were other groups to ask for help. Although previous studies (Holmes, Dalton, Erdmann, Hayden, \& Roberts, 1986; Lee \& Ekstrom, 1987) indicated that minority students tend to underuse counseling services, this study found no such clear pattern. In this study, a higher percentage of Black students than White students re-ported seeking help from counselors. Findings were based on a younger population, and it is unclear whether increased attention and effort were given to younger minority students by counselors, or if less effort was given to the older minority students. It is also unclear if students in this study self-referred for help or if counselors initiated the assistance. Although White students in general were less likely to obtain assistance from counselors than were the other groups, there was no evidence that they were more likely than were other groups to seek help from other resources (e.g., parents, friends, or relatives). It is possible that White students tend to be internally controlled (Sue, 1978) and, thus, less likely to seek external help. Perhaps, instead, minority students were more likely to be perceived or classified as low achievers and, thus, were more likely than were White students to be encouraged to seek help (Sue \& Sue, 1990). Further studies are needed to clarify this matter.

The findings are discouraging in that a relatively low percentage of students, regardless of their racial and sex background, consulted counselors or teachers for educational matters. Similarly, the final report of the Commission on Precollege Guidance and Counseling (1986) also indicated that many students have either little or no access to counselors at this critical time. As suggested by Lee and Ekstrom (1987), counselors may be so busy with paper work or other responsibilities that individual counseling and advising are rare. High student-to-counselor ratios also may limit the availability of counseling or advising services (Boyer, 1983). Nevertheless, counselors need to be aware of cultural barriers that may inhibit minority students from seeking counseling help, such as feelings of shame (Mau \& Jepsen, 1988) and differences in counseling expectancies (Altmaier \& Rapaport, 1984). 
The most troublesome finding is that most students turn to their peers for help while they underuse professional and expert help. Peers may not value educational achievement as much as do parents and other adults. More important, peers generally do not have the knowledge and experience to help with educational and vocational decisions. Because students preferred to talk to their peers, counselors may need to use approaches that are less threatening to students (Mau \& Jepsen, 1990) or that involve peers in the process.

Because students asked for parental help frequently, involving parents and other influential members of the family in the choices, plans, decisions, and learning activities of the students seems essential (Commission on Precollege Guidance and Counseling, 1986). Formal programs can be developed to assist parents of minority students in communicating to teachers and counselors their academic expectations for their sons and daughters (Atkinson, Morten, \& Sue, 1993). These programs also can be used by counselors to encourage parents to view educational choices in a realistic fashion, to help parents communicate these views to their children, and to help parents understand the curricular options and consequences of various academic choices (Commission on Precollege Guidance and Counseling, 1986).

\section{Educational Aspiration and Academic Achievement}

Regarding educational aspirations, most (98\%) eighth-grade students said that they would finish high school. Of these, about $20 \%$ plan to go to a vocational or technical school or attend college, and about $80 \%$ plan to finish college or continue further. In a recent longitudinal study of 10,500 high school seniors (see The Chronicle of Higher Education Almanac, August 26, 1992), however, only about $18 \%$ obtained a bachelor's or higher degree 6 years after high school graduation. Thus, high aspirations do not guarantee high educational attainments. Without appropriate planning and preparation, many students' dreams may never be fulfilled. Providing factual career information and educational and vocational planning seem especially important for middle school students.

This study and others (George, 1990; Heller, 1964; Malry, 1968) have shown that Hispanic and Native American students have lower levels of educational aspiration than do other student groups. Many Hispanic students may be recent immigrants or the children of recent immigrants. Because of language difficulties and financial pressure, these students often have to work and drop out of school. Hispanic students have a very high dropout rate, which increases with age (Sue \& Sue, 1990). To many Hispanic and Native American families, more schooling may be perceived as less practical or less rewarding because of financial and language constraints. Providing assistance to these students is critical so that a higher level of education becomes realistic for them.

Perceived parental expectation has been considered an important variable that is associated with individuals' educational and vocational attainments (Kerckhoff, 1989; Otto \& Haller, 1979; Smith, 1991). The discrepancy between students' own aspirations and their perceived parental expectations is an issue that requires counselors' attention. It may be important for counselors and educators to identify students who have a large discrepancy between their own aspirations and perceived parental expectations. Hispanic, Black, and Native American groups had a greater gap than did Asian American and White student groups. If these students desire to bridge that gap, they may need help. Faulty perceptions on the part of parents or students can cause pressure and tension and need to be identified.

Findings of this study lend little support for other studies which found that high aspirations of some minority students are transitory or are fantasies that have little relationship to school performance (Coleman, 1967; Epps, 1969). Current results indicate that students who do well academically tend to aspire to higher educational goals and vice versa; however, the association tends to be weaker for the Black, Hispanic, and Native American groups. How students' academic achievement affects level of aspiration, and vice versa, are matters for further investigation. Nevertheless, learning how to motivate students to learn and aspire to higher educational goals is important. It is appropriate for counselors and 
teachers to examine a student's level of educational aspiration in relation to his or her academic achievement.

It has been emphasized (Mau \& Jepsen, 1988, 1990) that one should be aware of stereotyping when working with an individual student. Counselors and teachers must be sensitive to the individual differences within each racial and ethnic group. The conclusions of this study are intended to help professionals plan intervention pro-grams for these potentially high-risk groups of minority students, but not to help stereotype them. Counselors must recognize that there are low achievers in a high-achieving group. They can become victims by being stereotyped and neglected, just as this can happen to high achievers within a low-achieving group.

As is true of any study using general broad-based survey data, the specific questionnaire items of interest were limited in scope and depth. For example, the questionnaire items regarding students' helpseeking behaviors did not allow students to indicate whether they made contact with helpers voluntarily or were approached by the helpers. Also, some data analyses were based on one-item responses only. Special attention needs to be given to the interpretation of the results. I should note that data based on self-report is subject to distortion by respondents because of imperfect recall, cultural differences in responding, social acceptability, and so forth. Some statistically significant findings also may be less meaningful in a practical sense. For instance, differences among racial groups in percentage of students who received help were very small for some items, but given the sample size, differences were statistically significant.

\section{CONCLUSION}

Counselors need to provide a program of guidance and counseling during early and middle school years, especially for students who traditionally have not been well served by the school system (Commission on Precollege Guidance and Counseling, 1986). Greater attention needs to be given to Hispanic and Native American students. Also, because girls were less likely than were boys to talk to counselors for educational and vocational planning, special efforts are needed to involve female students in the counseling process. Counselors need to be aware of multiple barriers that these particular groups face and develop programs to help students overcome both internal barriers, such as aspiration, motivation, and self-esteem, and external barriers, such as bias, stereotyping, and discrimination based on race, class, and sex.

\section{REFERENCES}

Altmaier, E. M., \& Rapaport, R. J. (1984). An examination of student use of a counseling service. Journal of College Student Personnel, 25, 453-458.

Apolloni, T., Feichtner, S. H., \& West, L. L. (1991). Learners and workers in the year 2001. The Journal for Vocational Special Needs Education, 14(1), 21-26.

Arbono, C. (1990). Career counseling research and Hispanics: A review of the literature. The Counseling Psychologist, 18, 300-323.

Atkinson, D. R., Morten, G., \& Sue, D. W. (1993). Counseling American minorities: A cross-cultural perspective (4th ed.). Dubuque, IA: Brown.

Baker, D. P. (1993). Compared to Japan, the U.S. is a low achiever ... really: New evidence and comment on Westbury. Educational Researcher, 22(3), 18-20.

Blau, P. M., \& Duncan, O. D. (1967). The American occupational structure. New York: Wiley.

Bound, J., \& Johnson, G. (1992). Changes in the structure of wages in the 1980's: An evaluation of alternative explanations. The American Economic Review, 82(3), 371-392.

Boyer, E. L. (1983). High school: A report on secondary education in America. New York: Harper \& Row. 
Brooks, L. (1984). Counseling special groups: Women and ethnic minorities. In D. Brown \& L. Brooks (Eds.), Career choice and development (pp. 255-268). San Francisco, CA: Jossey-Bass.

Brown, D., Minor, C. W., \& Jepsen, D. A. (1991). The options of minorities about preparing for work: Report of the second NCDA national survey. The Career Development Quarterly, 40, 5-19.

Coleman, J. (1967). Race relations and social change. Baltimore, MD: Johns Hopkins University, Maryland Center for the Study of Social Organization of Schools.

Commission on Precollege Guidance and Counseling. (1986). Keeping the options open: Recommendations. New York: College Entrance Examination Board.

Epps, E. G. (1969). Family achievement: A study of the relation of family background to achievement orientation and performance among urban Negro high school students. Ann Arbor, MI: Institute for Social Research, University of Michigan.

Fukuyama, M.A., \& Cox, C. I. (1992). Career needs in a diverse workplace: Implications of the NCDA gallup survey. In D. Brown \& C. W. Minor (Eds.), Asian-Pacific Islanders and career development (pp. 2750). Alexandria, VA: National Career Development Association.

George, C. A. (1990). Course enrollment practices of high school students in California. Sacramento, CA: California State Department of Education. (ERIC Document Reproduction Service No. ED 317 897)

Heller, C. S. (1964). Ambitions of Mexican American youth: Goals and means of mobility of high school seniors. Doctoral dissertation, Columbia University, New York.

Herr, E. L. (Ed.). (1992). The school counselor and comprehensive programs for work-bound youth. Alexandria, VA: American Counseling Association /National Occupational Information Coordinating Committee.

Holland, P. W., \& Thayer, D. T. (1986). Differential item functioning and the Mantel-Haenszel procedure (ETS Research Report No. 86-31). Princeton, NJ.

Holmes, D. R., Dalton, H. F., Erdmann, D. G., Hayden, T. C., \& Roberts, A. O. (1986). Frontiers of possibility: Report of the National College Counseling Project. Burlington, VT: University of Vermont, Instructional Development Center.

Hoyt, K. B. (1989). The career status of women and minority persons: A 20-year retrospective. The Career Development Quarterly, 37, 202-212.

Kerckhoff, A. C. (1989). On the social psychology of social mobility processes. Social Forces, 68, 17-25.

Kerr, B., Colangelo, N., Maxey, J., \& Christensen, P. (1992). Characteristics of academically talented minority students. Journal of Counseling \& Development, 70, 606-609.

Lee, V. E., \& Ekstrom, R. B. (1987). Student access to guidance counseling in high school. American Educational Research Journal, 24, 287-310.

Malry, L. (1968). The educational and occupational aspirations of Anglo, Spanish, and Negro high school students. Doctoral dissertation, University of New Mexico, Albuquerque.

Mau, W. C., \& Jepsen, D. A. (1988). Attitudes toward counselors and counseling processes: A comparison of Chinese and American graduate students. Journal of Counseling and Development, 63, 189-192.

Mau, W. C., \& Jepsen, D. A. (1990). Help-seeking perceptions and behaviors: A comparison of Chinese and American graduate students. Journal of Multicultural Counseling and Development, 18, 94-104.

National Center for Educational Statistics. (1990a). National education longitudinal study of 1988, base year: Student component data file user's manual (Report No. 90-464). Washington, DC: U.S. Department of Education.

National Center for Educational Statistics. (1990b). National education longitudinal study of /988: Base year sample design report (Report No. 90-463). Washington, DC: U.S. Department of Education.

National Center for Educational Statistics. (I 99 I). Psychometric report for the NELS:88: Base year test battery (Report No. 91-468). Washington, DC: U.S. Department of Education.

National Commission on Excellence in Education. (1983). A nation at risk: The imperative for educational reform. Washington DC: U.S. Government Printing Office. 
Otto, L. B., \& Haller, A. O. (1979). Evidence for a social-psychological view of the status attainment process. Social Forces, 57, 887-914.

Ponterotto, J. G. (1988). Racial/ethnic minority research in the Journal of Counseling Psychology: A content analysis and methodological critique. Journal of Counseling Psychology, 35, 175-182.

Sewell, W. H., \& Hauser, R. M. (1980). The Wisconsin study of social psychological factors in aspiration and achievements. Research in Sociology of Education and Socialization, 1, 59-99.

Smith, E. J. (1975). Profile of the Black individual in vocational literature. Journal of Vocational Behavior, 6, 41-59.

Smith, E. J. (1983). Issues in racial minorities' career behavior. In W. B. Walsh \& J. H. Osipow, (Eds.). Handbook of vocational psychology (Vol. I, pp. 161-222). Hillsdale, NJ: Erlbaum.

Smith, T. E. (1991). Agreement of adolescent educational expectations with perceived maternal and paternal educational goals. Youth and Society, 23, 155-174.

SPSS. (1990). SPSS base system user's guide. Chicago IL: Marija Norusis/ SPSS.

Stevenson, H. W. (1992). Learning from Asian schools. Scientific American, 267, 70-76.

Sue, D. W. (1978). Eliminating cultural oppression in counseling: Toward a general theory. Journal of Counseling Psychology, 25, 419--428.

Sue, D. W. (1992). The challenge of multiculturalism: The road less traveled. American Counselor, 1(1), 614.

Sue, D. W., \& Sue, D. (1990). Counseling the culturally different: Theory and practice (2nd ed). New York: Wiley.

Super, D. E. (1969). Vocational development theory. The Counseling Psychologist, 1, 2-30.

Thompson, C. E., \& Atkinson, D. R. (1991). Counseling visible racial/ethnic group men and women. In D. Capuzzi \& D. R. Gross (Eds.), Introduction to counseling: Perspective for the 1990s (pp. 388--415). Needham Heights, MA: Allyn \& Bacon.

United States Bureau of the Census. (1990). Statistical abstract of the United States. Washington, DC: U.S. Government Printing Office.

United States Department of Labor. (1988). Opportunity 2000: Creative affirmative action strategies for a changing workforce. Indianapolis, IN: Hudson Institute.

United States Department of Labor. (1991). What work requires of schools: A SCANS report for America 2000. Washington, DC: U.S. Government Printing Office.

U.S. Department of Labor. (1992). Apprenticeship. Occupational Outlook Quarterly, 35(4), 27-31. 